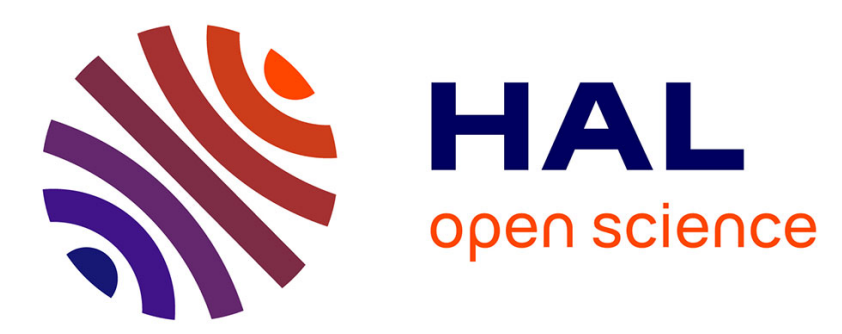

\title{
Aide à la classification des fractures du cotyle par segmentation des fragments osseux
}

\author{
Mehdi Boudissa, Matthieu Chabanas, Jérôme J. Tonetti
}

\section{To cite this version:}

Mehdi Boudissa, Matthieu Chabanas, Jérôme J. Tonetti. Aide à la classification des fractures du cotyle par segmentation des fragments osseux. 90e Réunion annuelle de la SOFCOT, 2015, Paris, France. pp.S205-S206, 10.1016/j.rcot.2015.09.163 . hal-01233930

\section{HAL Id: hal-01233930 \\ https://hal.science/hal-01233930}

Submitted on 4 Jan 2017

HAL is a multi-disciplinary open access archive for the deposit and dissemination of scientific research documents, whether they are published or not. The documents may come from teaching and research institutions in France or abroad, or from public or private research centers.
L'archive ouverte pluridisciplinaire HAL, est destinée au dépôt et à la diffusion de documents scientifiques de niveau recherche, publiés ou non, émanant des établissements d'enseignement et de recherche français ou étrangers, des laboratoires publics ou privés. 


\section{Aide à la classification des fractures du cotyle par segmentation des fragments osseux}

Mehdi Boudissa *, Matthieu Chabanas, Jérôme Tonetti

CHU Grenoble Alpes, Univ Grenoble Alpes, Boulevard de la Chantourne 38700 La Tronche

* Auteur correspondant.

Adresse e-mail : mboudissa@chu-grenoble.fr (M. Boudissa)

Background

The classification of acetabular fractures proposed by Letournel and Judet in 1961 is currently the most widely used system although its complexity and a wide variation in the interpretation. Development of CT scans with 2D then 3D reconstructions allow a better comprehension of fracture patterns. Questions purposes We thought that the exopelvic and endopelvic views of a 3D model reconstruction of acetabular fracture which separates each bone fragments by semi-automatic segmentation are sufficient to get a correct classification according to Letournel descriptions.

Methods

Six orthopedic surgery residents without specific knowledge in acetabular surgery had to classify 23 acetabular fractures using conventional 3D fixed reconstructions. Fractures were presented in an aleatory order for 2 minutes. Participants did not know whether their classification was correct or not. They were instructed that each of the 10 fracture patterns may be used more than once or not at all. They had to do the same 15 days later using our segmented exopelvic and endopelvic 3D reconstructions performed with the non-commercial software itksnap 3.0. This software allowed segmentation of each coxal bony fragment with a specific color. We then compared the number of correct responses from the two sessions and determined whether the use of the new 3D reconstructions exopelvic and endopelvic views influenced correct classification. Improvement in correct classification was assessed using the Mac Nemar test. Statistical analysis was performed using Statview 5.5 (SAS Institute, Cary, NC, USA). If the P-value was lower than the chosen alpha value of 0.05 , the difference was considered significant.

Results

We found a significant improvement in classifying acetabular fractures with the new 3D reconstructions ( $81 \pm 2 \%$ versus $52 \pm 7 \%, \mathrm{P}<0.001)$. The improvement was better for simple patterns $(100 \%$ versus $47 \%, \mathrm{P}<0.0001)$ than for associated patterns $(75 \%$ versus $53 \%, \mathrm{P}<0.001)$ with our 3D specific reconstructions.

\section{Conclusion}

The use of computed tomography image segmentation which separates each bone fragments is an effective tool for orthopedic resident education and training in acetabular fracture classification. This study supports a wider use of such imaging technology in clinical practice.

Disclosure of interest

The authors declare that they have no conflicts of interest concerning this article.

http://dx.doi.org/10.1016/j.rcot.2015.09.163

Aide à la classification des fractures du cotyle par segmentation des fragments osseux Revue de Chirurgie Orthopédique et Traumatologique, Volume 101, Issue 7, Pages S205-S206 Mehdi Boudissa, Matthieu Chabanas, Jérôme Tonetti 